\title{
'Brunswick' Strawberry
}

\author{
A.R. Jamieson ${ }^{1}$ and N.L. Nickerson ${ }^{2}$ \\ Agriculture and Agri-Food Canada, Atlantic Food and Horticulture Research \\ Centre, 32 Main Street, Kentville, NS, B4N 1J5, Canada
}

\author{
K.R. Sanderson ${ }^{3}$ \\ Agriculture and Agri-Food Canada, Crops and Livestock Research Centre, \\ 440 University Avenue, Charlottetown, PE, C1A 4N6, Canada
}

\section{J.-P. Privé ${ }^{4}$ \\ Agriculture andAgri-Food Canada, Senator HervéJ. Michaud Research Farm, 1045 St. Joseph Road, P.O. Box 2069, Bouctouche, NB, E4S 2J2, Canada}

\author{
R.J.A. Tremblay ${ }^{5}$ \\ N.B. Department of Agriculture, Fisheries, and Aquaculture, P.O. Box 6000, \\ Fredericton, NB, E3B 5H1, Canada
}

\section{P. Hendrickson ${ }^{6}$}

Nfld. Department of Forest Resources and Agrifoods, P.O. Box 2006, Corner Brook, NL, A2H 6J8, Canada

\section{Additional index words. Fragaria $\times$ ananassa, Phytophthora fragariae, fruit breeding}

The 'Brunswick' strawberry (Fragaria xananassa Duchesne) was commercially introduced in Canada in May, 1999 by the Atlantic Food and Horticulture Research Centre of Agriculture and Agri-Food Canada. 'Brunswick' ripens in early midseason, offering growers an alternative to 'Cavendish' with greater uniformity of fruit color and shape. Plants of 'Brunswick' are vigorous, resembling 'Cavendish' in habit, and they produce ample runners to establish matted rows. Plants are resistant to red stele root rot disease (incited by Phytophthora fragariae Hickman var. fragariae) and several leaf diseases. 'Brunswick' is named after the $\mathrm{Ca}$ nadian province of New Brunswick, a region where it performed well in early trials.

\section{Origin}

'Brunswick', tested as K90-12, is a seedling from a 'Cavendish' $\mathrm{x}$ 'Honeoye' cross

\footnotetext{
Received for publication 25 Feb. 2004. Accepted for publication 5 May 2004. Atlantic Food and Horticulture Research Centre Contribution no. 2276. We thank K.B. McRae, S. Fillmore, and B. Walker for assistance with experimental design and analysis. We thank the following cooperators who evaluated 'Brunswick' for suitability to their area: J. Madill (Ontario), C.G. Davidson (Manitoba), L. Hausher (Alberta), D.T. Handley (Maine), C. Weber (New York), K. Demchak (Pennsylvania), E.J. Hanson (Michigan), G.R. Nonnecke (Iowa), B.R. Smith (Wisconsin), and D.K. Wildung and J. Luby (Minnesota). For technical support, we thank A.C. Brydon, M. Graves, P. Rand, and R.J. Davies. For helpful comments on the manuscript, we thank John DeLong and John Lewis.

${ }^{1}$ Fruit breeder. Corresponding author; e-mail jamiesona@agr.gc.ca.

${ }^{2}$ Mycologist.

${ }^{3}$ Horticulturist.

${ }^{4}$ Fruit crop physiologist.

${ }^{5}$ Small fruit specialist.

${ }^{6}$ Horticulturist, retired.
}

date (Moore,1970). Mean harvest date was also weighted by yield in the same way. All statistics were calculated with Genstat 5.31 (Payne, 2000).

Fruit firmness was determined by penetration using an Ametek firmness tester (Ametek, Hunter Spring Division, Hatfield, Pa.) with a 6-mm-o.d. v-notched tip. Secondary berries, red-ripe, were carefully selected to avoid over-ripe berries and picked to avoid bruising. The maximum force that occurred during insertion of the probe $6 \mathrm{~mm}$ into each of 10 fruit was recorded. Two measurements were made per berry (darker and lighter red sides) and these were averaged to give a mean berry value. The 10 means were averaged and the standard error was calculated to show the variation around the cultivar mean.

Plants of 'Brunswick' are vigorous and produce moderate numbers of runner plants, similar to 'Cavendish' but less than 'Honeoye'. Matted rows of 'Brunswick' are less dense and more open than 'Honeoye', but often more dense than 'Cavendish'. Crown size is small to medium. Leaves are trifoliate: the central leaflet is slightly longer than wide, with an acute base and obtuse serrations. 'Brunswick' and 'Cavendish' leaflets tend to be cupped but 'Honeoye' leaflets tend to be flat. Leaf petioles are medium long with a medium to high density of outwardly oriented hairs. Flower clusters are produced on medium long peduncles, longer than for 'Cavendish' and 'Honeoye', and flowers open slightly beneath the canopy, similar to 'Honeoye'. Petals of 'Brunswick' are as wide as they are long and flowers are large $[31 \pm 0.6 \mathrm{~mm}$ (diameter \pm SE) for secondary flowers], similar to 'Honeoye' ( $30 \pm 0.7 \mathrm{~mm})$, but larger than 'Cavendish' (26 $\pm 0.7 \mathrm{~mm})$.

Fruit are large (Table 1) and typically ovoid to short conic in shape, broader than 'Honeoye' (Fig. 1). The larger primary fruit have a broad tip giving a wedge shape. 'Brunswick' fruit are more even in shape and color than 'Cavendish'. For secondary berries, the calyx is typically appressed to the fruit and its diameter is smaller than the diameter of the fruit. Calyx removal from the fruit is easier than for 'Cavendish' but more difficult than 'Honeoye'. Fruit surface is medium glossy, medium to dark red with a medium red interior flesh color. The flavor of 'Brunswick' is usually rated as good, more intense but less sweet than 'Cavendish', with tartness slightly less than 'Honeoye'.

In field plots, the firmness of the flesh of 'Brunswick' and 'Cavendish' berries are most commonly rated as medium to firm whereas 'Honeoye' is rated medium, and 'Jewel' is rated as firm. Field ratings of berry skin toughness are medium to firm for 'Brunswick' and firm for 'Jewel' (data not shown). Pressure tests have placed 'Brunswick' below 'Jewel' but more firm than 'Honeoye' (Table 2).

'Brunswick' ripens in the early midseason or midseason, depending upon the trial. In different trials, its harvest period has been earlier than 'Honeoye' to later than 'Cavendish'. In the Atlantic regional trials, the seasonal average harvest date of 'Brunswick', when 
Table 1. Fruit production ${ }^{2}$ of 'Brunswick' and standard cultivars for 1995 to 2000 averaged over sites in Atlantic Canada.

\begin{tabular}{|c|c|c|c|c|}
\hline \multirow[b]{2}{*}{ Cultivar } & \multicolumn{2}{|c|}{ Yield $\left(\mathrm{t} \cdot \mathrm{ha}^{-1}\right)$} & \multirow{2}{*}{$\begin{array}{c}\mathrm{Wt} / \text { fruit } \\
(\mathrm{g})\end{array}$} & \multirow{2}{*}{$\begin{array}{l}\text { Mean harvest } \\
\text { (day of year) }\end{array}$} \\
\hline & Marketable & Unmarketable & & \\
\hline \multicolumn{5}{|c|}{$1995(\text { Sites } 1,2,3,4)^{y}$} \\
\hline Brunswick & $15.0 \mathrm{~b}^{\mathrm{x}}$ & $1.5 \mathrm{~b}$ & $15.2 \mathrm{~b}$ & $195.0 \mathrm{~b}$ \\
\hline Cavendish & $14.9 \mathrm{~b}$ & $1.8 \mathrm{~b}$ & $18.8 \mathrm{a}$ & $195.3 \mathrm{~b}$ \\
\hline Kent & $19.3 \mathrm{a}$ & $2.2 \mathrm{a}$ & $13.9 \mathrm{c}$ & $197.0 \mathrm{a}$ \\
\hline \multicolumn{5}{|c|}{1996 (Sites 1,2,3,4) } \\
\hline Brunswick & $14.9 \mathrm{a}$ & $1.7 \mathrm{~b}$ & $10.9 \mathrm{~b}$ & $194.9 \mathrm{~b}$ \\
\hline Cavendish & $15.1 \mathrm{a}$ & $1.7 \mathrm{~b}$ & $12.5 \mathrm{a}$ & $195.4 \mathrm{~b}$ \\
\hline Kent & $17.1 \mathrm{a}$ & $2.2 \mathrm{a}$ & $10.5 \mathrm{~b}$ & $197.3 \mathrm{a}$ \\
\hline \multicolumn{5}{|l|}{1997 (Site 1) } \\
\hline Brunswick & $11.6 \mathrm{a}$ & $0.7 \mathrm{a}$ & $11.4 \mathrm{a}$ & 193.9 a \\
\hline Cavendish & $12.0 \mathrm{a}$ & $0.6 \mathrm{a}$ & $12.6 \mathrm{a}$ & $195.0 \mathrm{a}$ \\
\hline \multicolumn{5}{|l|}{1998 (Site 1) } \\
\hline Brunswick & $16.1 \mathrm{~b}$ & $1.0 \mathrm{a}$ & $12.8 \mathrm{a}$ & $181.0 \mathrm{c}$ \\
\hline Honeoye & $15.2 \mathrm{~b}$ & $0.6 \mathrm{a}$ & $10.8 \mathrm{~b}$ & $182.8 \mathrm{~b}$ \\
\hline Mira & $21.5 \mathrm{a}$ & $0.9 \mathrm{a}$ & $11.4 \mathrm{~b}$ & $186.4 \mathrm{a}$ \\
\hline \multicolumn{5}{|c|}{2000 (Sites $1,2,5$ ) } \\
\hline Brunswick & $12.7 \mathrm{a}$ & $1.0 \mathrm{~b}$ & $14.8 \mathrm{a}$ & $195.3 \mathrm{~b}$ \\
\hline Jewel & $15.2 \mathrm{a}$ & $1.0 \mathrm{~b}$ & $12.6 \mathrm{~b}$ & $197.7 \mathrm{a}$ \\
\hline Mira & $15.6 \mathrm{a}$ & $1.3 \mathrm{a}$ & $12.6 \mathrm{~b}$ & $197.9 \mathrm{a}$ \\
\hline
\end{tabular}

${ }^{2}$ Data for 1995 and 1996 from plots established in 1994; data for 1997 from plots established in 1996; data for 1998 from plots established in 1997; data for 2000 from plots established in 1999. Data from entire trials, containing 14 to 16 cultivars or selections, were used in the Analysis of Variance in which sites were a source of variance in the model and considered random.

'Trial locations: $1=$ Kentville, N.S.; $2=$ Charlottetown, P.E.I.; $3=$ Bouctouche, N.B.; 4 = Pynn's Brook, Nfld.; 5 = Belleisle Creek, N.B.

${ }^{\mathrm{x}}$ Mean separation within columns and years by least significant difference test at $P \leq 0.05$.

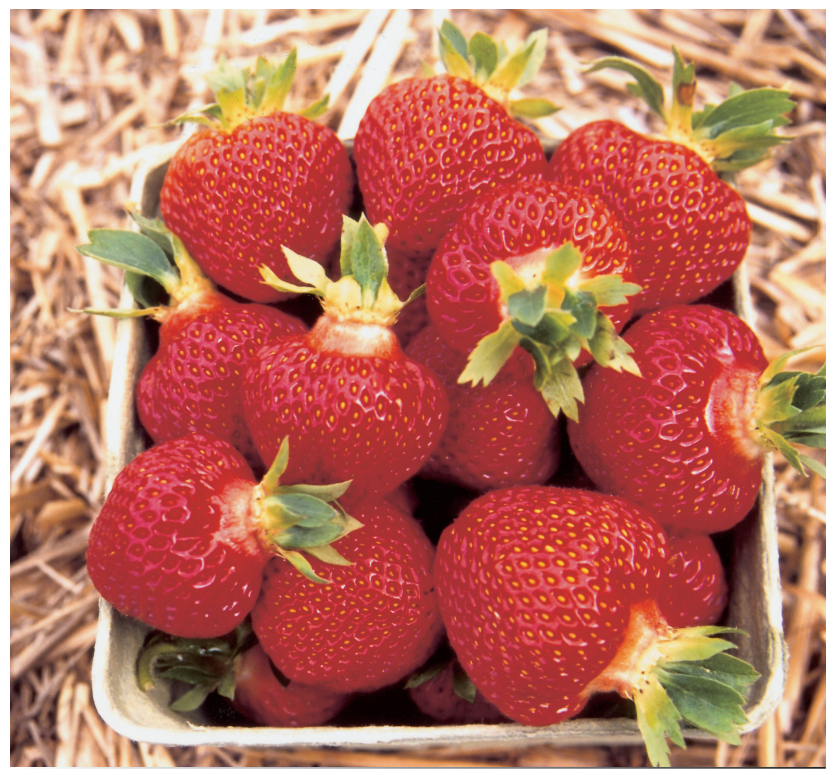

Fig. 1. Primary 'Brunswick' strawberries.

Table 2. Mean fruit firmness of 10 berries of 'Jewel', 'Brunswick', 'Cavendish', and 'Honeoye' harvested red-ripe.

\begin{tabular}{lcc}
\hline Cultivar & $\begin{array}{c}\text { Firmness }^{2} \\
(\mathrm{~N})\end{array}$ & SE \\
\hline Jewel & 3.6 & 0.06 \\
Brunswick & 3.4 & 0.14 \\
Cavendish & 3.3 & 0.08 \\
Honeoye & 3.1 & 0.15 \\
\hline
\end{tabular}

${ }^{2}$ Fruit firmness in Newtons as determined by penetration using an Ametek firmness tester with a 6-mm o.d. v-notched tip. The maximum force that occurred during insertion of the probe $6 \mathrm{~mm}$ into both sides of each of 10 fruit was recorded and averaged.

weighted according to the yield at each harvest, is usually not different from the harvest date for 'Cavendish' (Table 1).
'Brunswick' fruit weight, when averaged over the harvest season, is typically larger than 'Honeoye' but smaller than 'Cavendish' (Table 1). In the Atlantic regional trials, fruit yields have been medium to high, similar to 'Cavendish' but less than the high yielding 'Kent' or 'Mira' (Table 1). In a trial in Maine, the yield of 'Brunswick' equalled 'Mira', and fruit were described as firm, dark, and with good flavor (Handley and Dill, 2002). In Minnesota, where strawberry trials consist of mulched and unmulched plots and winter injury is expressed as a reduction in plant

spot [caused by Mycosphaerella fragariae (Tul.) Lindau]. 'Brunswick' leaves and fruit are slightly more resistant to powdery mildew [caused by Sphaerotheca macularis (Wallr.: Fr.) Jacz. f. sp. fragariae] than 'Cavendish', which is susceptible. 'Brunswick' exhibits moderate tolerance to fruit rot (caused by Botrytis cinerea Pers.:Fr.), a level similar to 'Cavendish'. 'Brunswick' is susceptible to crown rot [caused by Phytophthora cactorum (Lebert \& Cohn) J. Schröt.]. Virus diseases of strawberries are uncommon in Atlantic Canada, and the virus tolerance of 'Brunswick' is unknown. However, green petal disease (caused by clover phyllody phytoplasma) is common and 'Brunswick' plants show a level of susceptibility similar to 'Cavendish' but greater than 'Honeoye' which demonstrates resistance.

'Brunswick' appears to be well adapted throughout eastern Canada, northeastern U.S. and in all but the coldest strawberry-growing zones of north-continental regions of North America. 'Brunswick' will be of particular value on soils infested with $P$. fragariae var. fragariae, providing large, attractive, richly colored berries in the early midseason for local markets.

\section{Availability}

Certified 'Brunswick' plants are being propagated under royalty agreements with licensed nurseries, the names of whom will be supplied upon request. The Atlantic Food and Horticulture Research Centre has been granted Plant Breeder's Rights for 'Brunswick' (Certificate No. 0618) and a U.S. plant patent application has been filed. Nurseries interested in securing a propagating license may contact A.R.J., Agriculture and AgriFood Canada, Atlantic Food and Horticulture Research Centre, 32 Main St., Kentville, NS, B4N 1J5, Canada or jamiesona@agr.gc.ca.

\section{Literature Cited}

Handley, D.T. and J.F. Dill. 2002. Performance of strawberry cultivars grown in narrow matted row system in Maine, p. 32-36. In: S.C. Hokanson and A.R. Jamieson (eds.). Strawberry research to 2001. ASHS Press, Alexandria,Va.

Jamieson, A.R., K.A. Sanford, and N.L. Nickerson. 1991. 'Cavendish' strawberry. HortScience 26:1561-1563.

density from the fall to the spring or as lower plant vigor, 'Brunswick' plants were rated for hardiness as good, compared to very good for 'Cavendish' and excellent for Mesabi ${ }^{\mathrm{TM}}$ (D.K. Wildung and J.Luby, personal communications).

\section{Disease Response}

In greenhouse bench tests, 'Brunswick' has proven resistant to race A-6 of $P$. fragariae var. fragariae. Its reaction to other races has not been tested. Red stele symptoms have not been observed on 'Brunswick' in nine years of field testing. In field plots at Kentville, 'Brunswick' plants have demonstrated resistance to leaf scorch [caused by Diplocarpon earliana (Ellis \& Everh.) F.A. Wolf], and leaf
Moore, J.N. 1970. Fruit size of strawberry cultivars. Fruit Var. Hort. Dig. 24:58-62.

Nickerson, N.L. and A.R. Jamieson. 1995. Canadian races of the red stele root rot fungus, Phytophthora fragariae var. fragariae. Adv. Strawberry Res. 14:31-35.

Payne, R.W.(Editor). 2000. The guide to GenStat ${ }^{\circledR}$. part 2. Statistics. VSN Intl. Ltd. Oxford, U.K.

Sanford, J.C., D.K. Ourecky, J.E. Reich, and H.S. Aldwinckle. 1982. 'Honeoye' and 'Canoga' strawberries. HortScience 17:982-984.

Scott, D.H., A.D. Draper, and J.L. Maas. 1976. Mass screening of young strawberry seedlings for resistance to Phytophthora fragariae Hickman. HortScience 11:257-258.

Van de Weg, W.E. 1997. A gene-for-gene model to explain interactions between cultivars of strawberry and races of Phytophthora fragariae var. fragariae. Theor. Appl. Genet. 94:445-451. 